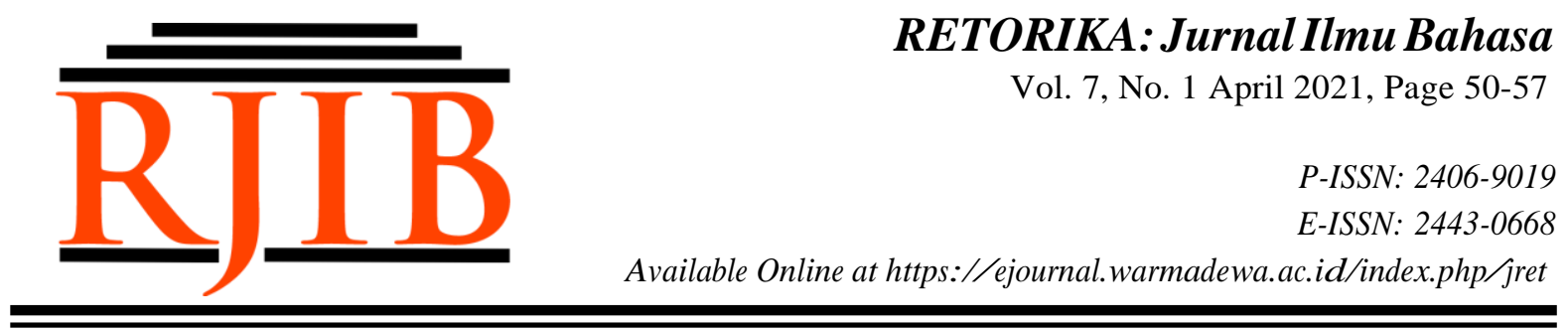

\title{
Diction and Message Logic in the Podcast of Deddy Corbuzier in Episode "Malih, Pesan Pedas Tuk Ade Londok"
}

\author{
Ronald Umbas $^{1 *}$, I Gusti Agung Sri Rwa Jayantini ${ }^{2}$ \\ ${ }^{1}$ STISPOL Wira Bhakti, ${ }^{2}$ Universitas Mahasaraswati Denpasar \\ *ronaldumbas1@gmail.com
}

\begin{tabular}{|c|c|}
\hline & Published: 30/04/2021 \\
\hline How to cite (in APA style): & \\
\hline $\begin{array}{l}\text { Umbas, R. \& Jayantini, I. G. A. S. R. (2021). Diction and Message Logic in the } \\
\text { "Malih, Pesan Pedas Tuk Ade Londok". Retorika: Jurnal } \\
\text { https://doi.org/10.22225/jr.7.1.2902.50-57 }\end{array}$ & $\begin{array}{l}\text { Podcast of Deddy Corbuzier in Episode } \\
\text { Ilmu Bahasa, 7(1), 50-57. doi: }\end{array}$ \\
\hline
\end{tabular}

\begin{abstract}
This study aims to identify diction which is related to message logic in communicating on social media. The identification is carried out based on Deddy Corbuzier's podcast that is aired on YouTube. The analysis of diction is an interesting study when, as one of the reasons, it is related to the efforts to effectively convey messages that are beneficial to a society. This study combines the concept of diction and Message Logic Theory, particularly "message design logic." The method applied is observation on the data source in the form of a video recording with note-taking techniques by which identification, classification and data reduction could be carried out. There are two main results in this study. First, the diction includes general words consisting of graded words and abstract words, and particular words consisting of proper names and the words that have suggestive power. Second, the dominant message logic that appears in Deddy Corbuzier's podcast episode "Malih, Pesan Pedas Tuk Ade Londok" (Malih, Sharp Message for Ade Londok) is expressive logic and rhetorical logic. The implication of this research on diction and communication logic is a description of the importance of choosing the right words in public spaces. This study also recommends other researchers to do further researches by using more speech data so that public communication patterns can be mapped better.
\end{abstract}

Keywords: Communication, Diction, Message Logic

\section{INTRODUCTION}

Communication on various social media is increasingly interesting. The growth of social media in the era of 4.0 industrial revolution forms various new ways of communication, especially in the public space. Previously, mass media was the central source in obtaining various information. Now the social media owned by an individual can become a very broad and fast broadcast media. A social media contains any kinds of information that is packaged creatively, informatively and draws attention. To produce these kinds of information, ideal communication principles must be applied. Communication can occur in various contexts, for example in the field of work, use of technology, and cultural engagement. In addition, communication also occurs at various levels, namely interpersonal communication that occurs between individuals, communication that occurs in small groups of individuals, and organizational communication involving individuals and groups (Morissan, 2014).

Regarding the existence of communication as a form of conveying messages from one party to another, O'Keefe (1988)'s Message Logic is an option to 
supporting the analysis of this study. O'Keefe's message logic in (Morissan, 2014) is divided into three components, namely expressive logic, conventional logic, and rhetorical logic. Expressive logic is a logic that considers communication as an attempt to self-expression so that the contents of thoughts and feelings can be expressed. The logic of this message is selfcentered by placing the speaking party as the center of attention. Consequently, other parties do not have enough opportunity to deliver messages. The second logic is conventional logic. This logic assesses communication as an event that must be properly organized according to rules and norms. This logic is suitable to be applied in formal situations that are designed to involve people with different social status so that norms can be applied properly. The third is rhetorical logic, which is a message logic that can change the rules through negotiation. The rhetorical logic is more open with the existence of a more flexible communication space with the focus of attention is on the interlocutors.

The quality of diction in conversations on social media can be assessed by looking at diction accuracy. This means that in every interaction, accuracy in choosing words is required. Keraf (2006) explains that there are a number of ways to see the accuracy of diction in communication. One of the methods is the use of general words and special words. This application can be an interesting study in terms of linguistics and communication science. The source of the data is the utterances that take place in an interview between two public figures.

Furthermore, Keraf (2006) divides general words into two, namely words that are graded from general to specific and abstract words, and divides particular words into two, the words that express proper names and the words that are suggestive. Communication that is manifested in various domains and groups becomes a study that can be seen from various linguistic phenomena, such as diction, language style and the accuracy of its use (Yuliana, 2010; Widyanto, 2018; Kayep, 2018; Damayanti, 2018; Fajriyani et al., 2020). In addition, communication that occurs in the media, in various activities and programs, can be analyzed from various perspectives. Language politeness in mass media is a basis for communication between the parties (Jainuri \& Mauliddian, 2019; Embarsari, 2019; Rafita et al., 2020). The use of language on social media needs to be taken into account by its users (Iswara \& Susana, 2019). The jargon that appears in the public domain can also be an interesting study when viewed from the structure of the jargon (Dwi Setiadi, 2019). The variety of communication in the mass media can also be seen from a semiotic perspective to expose verbal and visual signs in campaign advertisements (Putri, 2020). Discussions about the accuracy of diction, language politeness, and the structure of the message conveyed can be used as references to improving the quality of communication.

This study focuses on speech data found in Deddy Corbuzier's podcast on the YouTube channel. This communication medium is defined as a digital audio file that can be taken from the internet and played on a computer or a device that you can carry with you (https://www.oxfordlearnersdictionaries.com/def inition/english/podcast). In Indonesian, podcast is referred to as "siniar" which has become a new vocabulary. "Siniar" is described in Great Dictionary of the Indonesian Language as "siaran (berita, music, dan sebagainya) yang dibuat dalam format digital (baik audio maupun video) yang diunduh melalui internet" (broadcast (news, music, etc.) made in a digital format (both audio and video) which is downloaded via the internet (https://kbbi.kemdikbud.go.id/entri/siniar).

Based on the definition of Wikipedia (https://id.wikipedia.org/wiki/Siniar), "podcast" is a "siaran web tanalir" (non-streaming webcast). As a way of providing information widely in the midst of a mass media industry that is full of creativity, podcasters can steal attention as a form of digital communication media (both audio and video). Everyone can enjoy broadcasts that are published within a certain time and can be downloaded via the internet network.

In particular, this study looks at a podcast broadcast by a YouTuber and mentalist, Deddy Corbuzier (hereinafter referred to as DC) who started a brilliant career in entertainment world as a mentalist. Then, he developed his career as a public figure by hosting a talk show on a private television station. The podcast presents an interview between DC and a comedian, Haji Malih (hereinafter referred to as HM) who is also known as Malih Tong Tong. $\mathrm{HM}$ is a senior comedian who often performs the Betawi Lenong Art and also appears in other comedy forms both live and recorded on TVs 
and stages. In the episode "Malih, Pesan Pedas Tuk Ade Londok", DC and HM discuss the incident, which is considered an insult to HM as a senior comedian, caused by a young comedian named Ade Londok. DC and HM also discuss about the comedy world in Indonesia and HM's seniority and experience in this world. Given the interesting topic discussed by the public figures in a podcast and how diction leads to a more fascinating content that may attract a huge number of viewers, this study aims at identifying diction in relation to the existence of message logic when an interactive talk show is publicly shared through social media.

\section{METHOD}

This research is a qualitative descriptive research which was applied through observation method and note-taking techniques. The data source of this research is one of the episodes of

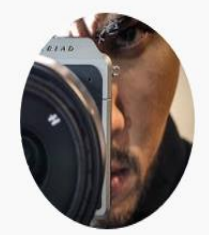

Deddy Corbuzier $\bullet$

12.7M subscribers $\cdot 745$ videos CLOSETHEDOOR PODCAST.

Deddy Corbuzier channel. Observation by watching the video was carried out to get the data from the podcast uploaded on YouTube channel

(https://www.youtube.com/watch? $\mathrm{v}=\mathrm{CNjJYC}$ w4WU) by DC. Furthermore, after social media spread and each person had a great opportunity to convey various information, YouTube has become the right choice for many artists and/or celebrities to spread and exchange information. The form of podcast that many YouTubers choose is interview.

\section{Figure 1 \\ The Podcast Screen Capture of Deddy Corbuzier on YouTube}

Observation was carried out by watching and listening carefully the data source which was an interview between DC and HM. This method was supported by the note-taking technique which was applied through the following steps.

(1) Identification

Identification was done by watching over and over again the podcast video which was used as the data source. The first step of identifying was watching the podcast fully without pausing. After the data which would be analyzed were found, identification was conducted again by watching the podcast the second time with several pauses to record dictions, which were classified according to the theory.

(2) Classification

Classification was carried out based on linguistic and communication theories, which are the bases of the analyses of this study. The meeting point of these two theories was used as a classification guide so that classified data were valid.

(3) Reduction

Reduction was a step to facilitate interpretation. Data reduction was important for the classification to become clear. Elimination of a number of irrelevant data was carried out by examining repeatedly the data in the identification and classification stages.

(4) Interpretation Interpretation step was very useful in the analysis and conclusion stages. This step was done by looking for relevant references to support the theory. In this case the classification of data was based on the concept of diction proposed by Keraf (2006) and the Logic Message Theory of O'Keefe (1988).

\section{RESULTS AND DISCUSSION}

There are two results of this study. First, the diction that was identified consists of graded general words, abstract words, the words that express proper names and the words that have suggestive power. Second, the dominant message logic in Deddy Corbuzier's podcast episode "Malih, Pesan Pedas Tuk Ade Londok" is rhetorical logic. The explanation of diction and message logic shows the importance of choosing the right words in social media so that the quality of interaction can be improved. The finding is line with the idea of assessing the quality of diction in conversations involving accuracy in the choice of appropriate words based on its context (Keraf, 2006). The investigation on diction can be done by observing the use of general words and special words. Here, identifying diction includes how general words covering words that are graded from general to specific and abstract words are utilized in DC's podcast. The finding also covers how particular words consisting of proper names and suggestive words are chosen 
in making the communication more vividly presented.

\section{Diction in Deddy Corbuzier's Podcast}

The diction includes graded general words and abstract words that belong to general words, and proper names words and suggestive words that belong to particular words. The graded general words and abstract words are consecutively shown in Table 1 and Table 2 while both proper names words and suggestive words are listed in Tabel 3.

\section{General Words}

Table 1 shows the presence of general words that are moving toward more specific words.
This causes the conversation in Deddy Corbuzier's podcast to flow better and be able to open up insights about the choice of words that can be used to describe something. Table 1 shows the presence of the word komedi that is general in nature and then it is shifting to more specific words; lawak, pelawak, komedian. This word becomes even more specific to lenong and topeng (mask) before it finally goes further to very specific words - Haji Malih, Bolot, Sule, Andre and Komeng. These are the names of famous comedians. Similarly, the word legend is graded more specifically to legenda hidup (living legend), senior, and Haji Malih.

Table 1

Common Words in Deddy Corbuzier's Podcast

\begin{tabular}{|l|l|l|l|}
\hline $\begin{array}{c}\text { Very } \\
\text { General }\end{array}$ & Less General & \multicolumn{1}{|c|}{ More Specific } & \multicolumn{1}{|c|}{$\begin{array}{c}\text { Very } \\
\text { Specific }\end{array}$} \\
\hline $\begin{array}{l}\text { Komedi } \\
\text { 'comedy' }\end{array}$ & $\begin{array}{l}\text { Lawak } \\
\text { 'comedy' } \\
\text { Pelawak } \\
\text { 'comedian' }\end{array}$ & $\begin{array}{l}\text { Lenong 'lenong' } \\
\text { (type of Betawi } \\
\text { comedy show) } \\
\text { Topeng 'topeng' } \\
\text { Komedian } \\
\text { 'type of Betawi } \\
\text { comedy) }\end{array}$ & $\begin{array}{l}\text { Holih } \\
\text { Sule } \\
\text { Andre } \\
\text { Komeng } \\
\text { Nomian' }\end{array}$ \\
\hline Legend & Living Legend & Senior & Haji Malih \\
\hline
\end{tabular}

In table 1, the word komedi and legend are classified into general words because there are other words that can be their branches. This branch is considered a gradation of meaning that becomes more specific. Thus, general words can be graded into very general, less general, more specific and very specific.

\section{Interview Excerpt 1}

DC "Tapi gini Bang Malih, memang dulu itu komedi ada belajarnya nggak sih?"

HM "Nggak ada"

DC "Nggak ada? Nah kalau orang ngelenong, orang apa segala itu, bukannya harus dipelajari?"

HM "Nggak ada. Jadi kalau kita kembali ke masalah topeng atau lenong. Kenapa nggak belajar lagi? pan ditunjuk ama sutradaranya, seperti saya ama Bokir. Lih, ntar lu jadi pembantu. Ya udah."

DC "Udah, tuh? Semuanya improvisasi?"

Translation:

DC "Well...let me ask you a question, Bang
Malih, was there any comedy lesson you learned before?"

HM No, there wasn't any"

DC "There wasn't? So when people would perform a lenong, didn't they have to memorize the script first?"

HM "No, they didn't. So if we go back to topeng or lenong. We were just told by the director. For example, Bokir told me, "Lih, you will be a maid." That's it.

DC "Is that all? Everything is improvised?

Interview excerpt 1 shows the general word komedi, which is used by DC in his question. HM answers DC's question by using the words topeng and lenong. He uses these two words to tell people about the existence of the topeng and lenong as types of comedy shows and how the people involved in them have to improvise during performance. By listening to the utterance of these words, which are more specific than komedi, people are hopefully able to better understand HM's opinions and know his experiences as a senior comedian. 
Table 2

Abstract Words in Deddy Corbuzier's Podcast

\begin{tabular}{|l|l|l|}
\hline \multicolumn{1}{|c|}{ Positive } & \multicolumn{1}{c|}{ Neutral } & \multicolumn{1}{c|}{ Negative } \\
\hline Etika 'ethics' & Kebiasaan 'habit' & Penghinaan 'insult' \\
Pendidikan'education" & & Kesalahan 'mistake' \\
Disiplin 'dicipline' & & Kelupaan 'careless' (based \\
Kejujuran 'honesty' & & on the context in the \\
Kemampuan'capability' & & conversation) \\
Lucu 'funny' & & Emosi'emotion' \\
& & Adem 'calm and do not \\
& & talk much' \\
\hline
\end{tabular}

The general words listed in table 2 show the abstract words that refer to the things related to the world of comedy (lawak) and the existence of the people who are involved in it. The categories positive, negative, and neutral are intended to show varieties of abstract words. The word abstrak means 'tidak berwujud' (not having physical or concrete existence); tidak berbentuk (not having a form) (https://kbbi.web.id/abstrak). The words in table 2 are classified as abstract words because the concepts that they have exist but are intangible and formless. An example of using abstract word is presented in the interview excerpt 2 which contains the word penghinaan (insult). The existence of this is significant and therefore, needs to be discussed.

Interview Excerpt 2:

DC "Yang dalam adegan yang wajar-wajar ajalah, namanya juga cari makan. Juga jangan berkelebihan. Berkelebihan, kalau kita bilang, over lo. Nah gitu. Udah..jangan dibahas lagi terus."

HM "Jadi turun, ya?"

DC "Jadi turun. Alah, Bang Malih udah tuatua masih ini aja. Udah cukup."

HM "Selesai di sana. Kalau dipanjangpanjangin jadi penghinaan."

DC "Penghinaan. Nanti kita jawab. Tua orangnya, tapi duitnya dong. Kan bisa."

Translation:

DC "When acting, let's just be proportional. We are all making a living here...so don't be excessive. It's excessive, we say, over, right. So that's it. We don't need to discuss it anymore."

HM "So, it's going down, right?"

DC "Going down. "Bang Malih is getting old, but doesn't change at all." Just say that and it's enough."

HM "Stop right there. If we are adding it, it will become an insult."

DC "Yes, an insult. But if they add it, we can answer, "I may be old, but I have much money." It could go like that."

\section{Particular Words}

The particular words identified in this DC's podcast are proper names and the suggestive words including non-standard words which have suggestive power and are very distinctive. In addition, some words have connotative meanings, for example the term laki bini (husband and wife) used by HM. He does not mean husband and wife in a marriage, but he means the solidity and chemistry between him and his partner Bolot, who is also a comedian. This word supports the explanation of the world of comedy in general and the news about Ade Londok's insult to him.

The proper names collected in Table 3 supported the topic of conversation and the general words mentioned by HM. Names such as Bolot, Bokir, Andre, Sule, Komeng, and Ade Londok are mentioned in the interview as the people who are involved in the art of comedy in Indonesia. These words, which belong to particular words, are used to support the explanation of the world of comedy in Indonesia.

Table 3 also shows the words that are suggestive such as the ones that have been mentioned before, i.e., laki and bini. A number of non-standard words also appear such as tektokan (a slang used to express good interactions), bete (a slang used to express boredom or a feeling of being upset, uncomfortable or annoyed), and keceplosan (a slang used to express accidentally uttered word or expression that is not supposed to be said.). HM also uses a suggestive word matahin, which, in this context, means a person's action that hinders a comedian from being funny when performing. 
Table 3

Specific Words / Terms in Deddy Corbuzier's Podcast

\begin{tabular}{|l|l|}
\hline \multicolumn{1}{|c|}{ Proper Names } & \multicolumn{1}{|c|}{ Words that have Suggestive Power } \\
\hline Bolot & Laki 'husband' \\
\hline Bokir & Wife 'bini' \\
\hline Sule & $\begin{array}{l}\text { Tektokan 'a slang used to express good } \\
\text { interactions) }\end{array}$ \\
\hline Komeng & $\begin{array}{l}\text { Bete 'a slang used to express boredom or a } \\
\text { feeling of being upset, uncomfortable or } \\
\text { annoyed.' }\end{array}$ \\
\hline Ade Londok & $\begin{array}{l}\text { Keceplosan 'a slang used to express } \\
\text { accidentally uttered word or expression that is } \\
\text { not supposed to be said.). }\end{array}$ \\
\hline $\begin{array}{l}\text { Matahin, 'a person's action that hinders a } \\
\text { comedian from being funny when } \\
\text { performing' }\end{array}$ \\
\hline
\end{tabular}

Some particular words in table 3 can be found in interview excerpt 3 . It is seen in this excerpt that HM implies that in comedy, good interactions and chemistry among comedians in a performance is a must. He confirms that being a comedian is a difficult thing. In other words, good interactions and chemistry between one comedian and another need a long time to achieve. Such a relationship is necessary for comedians so that they could support each other's performance in every show.

Interview Excerpt 3

DC "Makanya komedi adalah cocokcocokan."

HM "Betul. Makanya saya ama Bolot udah nggak bisa dipisahin, itu udah laki bini."

DC "Karena dia mau ngapain udah ketahuan."

HM "Udah tahu. Lu mau ngapain aja udah tahu. Susah, jadi pelawak itu nggak gampang."

Translation:

DC "That's why a comedy show needs good chemistry between players."

HM "That's right. That's why Bolot and I can't be separated, it's like laki bini."

DC "Because you always know what he wants to do."

HM "Yes. I always know anything he wants to do. It's not easy. It's hard to be a comedian."

\section{Message Logic in Deddy Corbuzier's Podcast} Rhetorical logic is the dominant message logic in the conversation between DC and HM. Rhetorical logic sees communication as a way that emphasizes more on negotiation. In the interview, DC seems to follow the flow of HM's speech as a guest. He tries to manage the messages he wants to convey in the conversation in which they talk not only about an insult that a young and far less comedian Ade Londok did but also about the world of comedy in Indonesia. The interaction that occurs in the delivery of messages is shown in Figure 2.

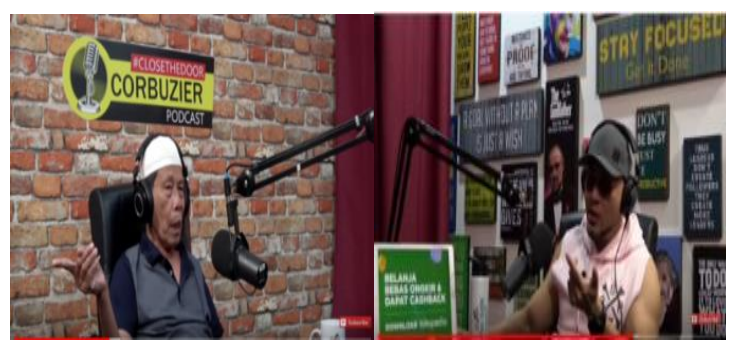

Figure 2

Interaction in Interview on Deddy Corbuzier's Podcast

As the interviewer, DC has placed the interviewee as a guest and has a central role. He provides a confirmation expression in the interview allowing the two parties to more openly share their ideas in this episode. This is important for interactions to run smoothly between the parties involved in a conversation. This is an example of reframing information which is one of the features of the rhetorical logic. The following interview excerpt gives us more insights about this specific matter.

Interview Excerpt 4:

DC "Ya Bang, ngeliatnya kok nggak enak gitu. Seorang Bang Malih jatuh seperti itu terus itu heboh dimana-mana. Ngeliat bahwa Bang Malih ini kan sudah senior."

HM "Ya..ya..ya"

DC "Kalau saya jadi Bang Malih, pasti bete 
gitu lho."

HM "Sebetulnya sih apa itu yang Mas Deddy bilang, kita juga sama seperti itu. Tapi itu kan dalam adegan, jadi kita juga bisa maklumi mungkin mereka lupa atau sengaja itu kita nggak tahu. Pada intinya, kita jangan ngambil hati setiap perbuatan adalah satu kesalahan saja. Gila ya, omongan gua tinggi amat ya, ha ha ha."

Translation

DC "Yes Brother, it wasn't a good thing to see. Bang Malih as a famous comedian fell down like that, and it became an incident many people talked about. Because Bang Malih is already a senior."

HM "Ya...уа...у.

DC "If I were Bang Malih, I would be upset, for sure"

HM "Actually, I was upset. But that was in the scene, so I understood regardless he did it on purpose or not. I didn't know. The point is, don't take it personally. Every action is just a mistake. Wow...it's crazy, isn't it? I'm talking like a wise man, ha ha ha."

In this particular interview, DC is applying message logic when communicating in the form of negotiation and by siding with HM. He attempts to reframe the situation in the form of a confirmation by saying "Ya Bang, ngeliatnya kok nggak enak gitu. Seorang Bang Malih jatuh seperti itu terus itu heboh dimanamana. Ngeliat bahwa Bang Malih ini kan sudah senior." The phrase "Ya Bang", followed by a statement leading to talking about the incident that happened to HM, shows that DC wants to gather information and does not only focus on himself. DC tries to gather opinions from HM and he replies DC with a confirmation expression, "ya ... ya ... ya ...". The confirmation made by the two parties allows negotiation to take place in the conversation.

Rhetorical logic emphasizes on the negotiation of the parties involved. It is intended to make those involved in a conversation feel appreciated. Interview excerpt 5 shows rhetorical logic that occurs in the dialogue between DC and HM. DC, as the interviewer, has positioned himself as the person in charge organizing the dialogue so that there is confirmation in their conversation. In an interview situation like this, maintaining the interviewee's feeling of comfort is very important.

\section{Interview Excerpt 5}

DC "Ya bener, memang bener, cuman kan Bang Malih ini kan legend."

HM "Legend apa sih?"

DC "Legend itu artinya sudah luar biasa"

HM "Udah luar tapi biasa gitu.

DC "Ya, sudah luar tapi biasa. Oh, living legend. Wow..Legenda hidup."

HM "Ah..bahasa lo, gua kagak ngarti dah."

Translation

DC : It's true, really true, but Bang Malih is a legend, right?

$\mathrm{HM}$ :What is legend?

DC : Legend means extraordinary.

HM : It's already extra but ordinary.

DC : Yes. Extra but ordinary. Oh, living legend. Wow...living legend.

HM : Ah..your language. I don't understand.

An example of maintaining a good relation and framing a situation in which both parties agree with each other is given by DC. In the interview excerpt 5, DC calls HM a legend. This means that DC makes a prologue in this piece of interview, a start of his rhetorical logic aimed at maintaining the role of one party. This effort is the negotiation in communication that is seen from DC's statement, "Ya bener, memang bener, cuman kan Bang Malih ini kan legend", which is replied HM by saying, "Legend apa sih?" To this question, DC answers, "Legend itu artinya sudah luar biasa." Even though HM finally says that he does not understand what DC says, it is clear in this context, that HM actually knows what DC means and does not deny the label legenda hidup (living legend) given to him by DC. The message logic is, then, applied through negotiation in which one party states something and the other responds by asking and confirming.

\section{CONCLUSION}

The diction that appears in Deddy Corbuzier's podcast in the episode of "Malih, Pesan Pedas Tuk Ade Londok" includes general words and particular words. The general words found are graded words and abstract words and the particular words identified consist of proper names and suggestive words. The use of these words is found in the conversation that discusses the world of comedy in Indonesia and its senior 
figures. The choice of words that enriches the viewers' insights needs to be considered by public figures because they are the center of information and can play a role in language enrichment through accurate and proper ways of speaking. Related to that, the dominant message logic is rhetorical logic, which is manifested in the attention given by the two parties. They have to negotiate with each other in the dialogue by developing good interaction between them. They could respond to each other smoothly and it seems they have created their own chemistry. They could not only add the knowledge of the viewers but also give a good example of how a good dialogue takes place in an interview. Words, phrases, and sentences they produce are significantly beneficial for this interaction. This research is expected to give insight into the importance of diction accuracy in managing interaction.

\section{REFERENCES}

Damayanti, R. (2018). Diksi Dan Gaya Bahasa Dalam Media Sosial Instagram. Widyaloka IKIP Widya Darma, 5(3), 261-278.

Dwi Setiadi, I. G. (2019). Jargon Capres - Cawapres Fiktif; Nurhadi - Aldo Dalam Wacana PraPemilu Di Indonesia Tahun 2019. KULTURISTIK: Jurnal Bahasa Dan Budaya, 3(2), 91.

Embarsari, I. F. (2019). Penyimpangan Prinsip Kesantunan Pada Vlog Awkarin (Kajian Pragmatik Culpeper). Sastra Indonesia, Linguistik, 1, 1-476.

Fajriyani, N., Ridho, M. R., \& Laili, Q. (2020). Analisis Kesalahan Berbahasa Di Bidang Diksi Dalam Buku Panduan Upt Perpustakaan Iain Surakarta Edisi 2018. Jurnal Penelitian Humaniora, 21(1), 55-68.

Putri, I.G.A.V.W. (2020). Semiotika Tanda Verbal Dan Visual Pada Iklan Kampanye Pencegahan Penyebaran Covid-19. KULTURISTIK: Jurnal Bahasa Dan Budaya, 4(2), 10-18.

Rafita, P, Saibi, E.A \& Ahadiat. E. (2019). Analisis Tuturan Kesantunan Pada acara ini talk show. E Journal of Bung Hatta. 2(10).

Iswara, A. A., \& Susana, K. Y. (2019). Analisis Kesantunan Bahasa Media Sosial: Komunikasi Mahasiswa Kepada Dosen Stmik Stikom Indonesia. KULTURISTIK: Jurnal Bahasa Dan Budaya, 3(2), 10.

Keraf, G. (2006). Diksi dan Gaya Bahasa (16th ed.). Jakarta: PT Gramedia Pustaka Utama.

Yuliana, R. (2010). Analisis Penggunaan Diksi Pada Artikel Surat Kabar Solo Pos. (skripsi). Solo: Universitas Muhammadiah Surakarta.

Jainuri, M. \& Mauliddian, K. (2019). “ Ini Talk Show "Tema Motivasi Di Net Tv Analysis of
Politeness in the Program " Ini Talk Show ." Kadera Bahasa, 11(1), 33-44.

Morissan. (2014). Teori Komunikasi Individual Hingga Massa. Jakarta: Kencana.

O'Keefe, B. J. (1988). The Logic of Message Design: Individual Differences in Reasoning About Communication. Communication Monograph.

Kayep, I. (2017). Analisis Ketepatan Diksi Pada Tajuk Rencana Surat Kabar Harian Merdeka Edisi Maret 2016.(skripsi) Yogyakarta: Universitas Sanata Dharma.

Widyanto, H. (2018). Analisis Diksi dan Gaya Bahasa dalam Iklan Barang dan Iklan Jasa Koran Pontianak Post Edisi Oktober 2016. (skripsi) Yogyakarta: Universitas Sanata Dharma

https://www.oxfordlearnersdictionaries.com/definitio n/english/podcast

https://kbbi.web.id/abstrak

https://kbbi.kemdikbud.go.id/entri/siniar

(https://www.youtube.com/watch?v=CNjJYC_w4W

U 